
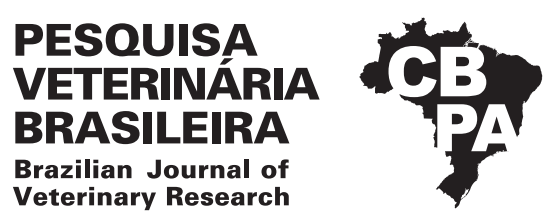

Pesq. Vet. Bras. 39(8):668-671, August 2019 DOI: 10.1590/1678-5150-PVB-6218

Original Article

ISSN 0100-736X (Print)

ISSN 1678-5150 (Online)

\title{
Serum amyloid $A$ and muscle activity biomarkers in horses submitted to equestrian show jumping ${ }^{1}$
}

\author{
Wilson P. Carvalho Filho ${ }^{2}$, Leandro A. Fonseca ${ }^{2 *}$ (D), Fabricia M. Girardi², \\ Lucas D. Bento ${ }^{3}$, Pollyanna C. Souto ${ }^{2}$ and Andres M.O. Orozco ${ }^{2}$
}

\begin{abstract}
Carvalho Filho W.P., Fonseca L.A., Girardi F.M., Bento L.D., Souto P.C. \& Orozco A.M.O. 2019. Serum amyloid $A$ and muscle activity biomarkers in horses submitted to equestrian show jumping. Pesquisa Veterinária Brasileira 39(8):668-671. Departamento de Medicina Veterinária, Universidade Federal de Viçosa, Campus Viçosa, Avenida Peter Henry Rolfs s/n, Campus Universitário, Viçosa, MG 36570-900, Brazil. E-mail: leandroabreu@ufv.br

The aim of this study was to evaluate the serum amyloid A (SAA) and biomarkers of muscle activity of horses submitted to show jumping activity. To do this, the variables SAA, glucose, lactate and the biomarkers creatine kinase (CK) and aspartate amino transferase (AST) were evaluated in 10 horses submitted to the show jumping exercise in a tournament for beginners. The evaluations occurred before exercise (T0), immediately after (T1), 30 minutes (T2), 60 minutes (T3) and 24 hours after the end (T4). Data were evaluated using analysis of variance for repeated measures. The statistical software SAEG 9.1 was used to verify the level of significance between the moments for $\mathrm{P}<0.05$. Glucose presented a difference between the moments T0 $(97.7 \pm 13.3 \mathrm{mg} / \mathrm{dL})$ and T1 $(79.7 \pm 14.1 \mathrm{mg} / \mathrm{dL})$. Lactate presented elevation in T1 $(15.3 \pm 6.1 \mathrm{mmol} / \mathrm{L})$ compared to the others T0 $(3.8 \pm 0.8 \mathrm{mmol} / \mathrm{L}), \mathrm{T} 2(6.5 \pm 3.9 \mathrm{mmol} / \mathrm{L})$, T3 $(5.3 \pm 2.2 \mathrm{mmol} / \mathrm{L})$ and T $4(5.1 \pm 1.6 \mathrm{mmol} / \mathrm{L})$. The CK showed a significant difference between T0 $(82.8 \pm 51.2 \mathrm{U} / \mathrm{L})$ and T1 $(140.1 \pm 58.5 \mathrm{U} / \mathrm{L})$ and between T4 $(74.4 \pm 43.1 \mathrm{U} / \mathrm{L})$ with T1 $(140.1 \pm 58.5 \mathrm{U} / \mathrm{L})$. The AST presented no difference between moments. The show jumping activity with one-meter obstacles did not induce changes in the SAA protein between the moments
\end{abstract}

INDEX TERMS: Serum amyloid A, muscle activity, biomarkers, horses, equestrian show jumping, acute-phase protein, inflammation, exercise, equine, morphology.

RESUMO.- [Biomarcadores de amilóide sérica A e de atividade muscular em cavalos submetidos a salto equestre.] $O$ objetivo deste estudo foi avaliar a amilóide sérica A (SAA) e biomarcadores de atividade muscular de equinos submetidos a atividade de salto, ou hipismo clássico. Para tanto, foram avaliadas as variáveis SAA, glicose, lactato e os biomarcadores creatina quinase (CK) e aspartatoaminotransferase (AST) em 10 equinos submetidos ao exercício de saltos em torneio para iniciantes. As avaliações ocorreram antes do exercício (T0), imediatamente após (T1), 30 minutos (T2), 60 minutos (T3) e 24 horas após o término (T4). Os dados foram avaliados utilizando análise de variância para medidas repetidas. 0 software estatístico SAEG 9.1 foi utilizado para verificar o nível de significância entre

\footnotetext{
${ }^{1}$ Received on February 22, 2019.

Accepted for publication on April 9, 2019.

${ }^{2}$ Departamento de Medicina Veterinária, Universidade Federal de Viçosa (UFV), Campus Viçosa, Avenida Peter Henry Rolfs s/n, Campus Universitário, Viçosa, MG 36570-900, Brazil. *Corresponding author: leandroabreu@ufv.br

${ }^{3}$ Universidade Federal de Minas Gerais (UFMG), Avenida Pres. Antônio Carlos 6627, Pampulha, Belo Horizonte, MG 31270-901, Brazil.
}

os momentos para $\mathrm{P}<0,05$. A glicose diferenciou-se entre os momentos T0 $(97.7 \pm 13.3 \mathrm{mg} / \mathrm{dL})$ e T1 $(79.7 \pm 14.1 \mathrm{mg} / \mathrm{dL})$. 0 lactado apresentou elevação comparada com o momento $\mathrm{T} 1(15.3 \pm 6.1 \mathrm{mmol} / \mathrm{L})$ e os demais T0 $(3.8 \pm 0.8 \mathrm{mmol} / \mathrm{L})$, T2 $(6.5 \pm 3.9 \mathrm{mmol} / \mathrm{L}), \mathrm{T} 3(5.3 \pm 2.2 \mathrm{mmol} / \mathrm{L})$ e T4 $(5.1 \pm 1.6 \mathrm{mmol} / \mathrm{L})$. A CK mostrou diferença significativa entre T0 $(82.8 \pm 51.2 \mathrm{U} / \mathrm{L})$ e T1 $(140.1 \pm 58.5 \mathrm{U} / \mathrm{L})$ e entre T4 $(74.4 \pm 43.1 \mathrm{U} / \mathrm{L})$ com T1 $(140.1 \pm 58.5 \mathrm{U} / \mathrm{L})$. A AST não apresentou diferença entre os momentos. A atividade de hipismo clássico com obstáculos de um metro não induziu alterações na proteína SAA entre os momentos.

TERMOS DE INDEXAÇÃO: Biomarcadores, amilóide sérica A, atividade muscular, cavalos, salto equestre, proteínas de fase aguda, biomarcadores musculares, inflamação, exercício, hipismo, equinos, morfologia.

\section{INTRODUCTION}

Equestrian sporting activities are increasingly evident in the world and the show jumping is the sport that stands out most among sports with horses. According to the International 
Equestrian Federation (Fédération Equestre Internationale 2013), almost 65 thousand animals are registered in the entity and more than 50 percent belong to the modality of show jumping. However, this type of exercise induces intense structural and metabolic changes and adaptations, which depend on adequate stimulus and must be monitored (Fazio et al. 2014). It is a sport that involves the largest number of horses in the world. Like any sport, in show jumping there are two important challenges that are to ensure the animal's health and to improve athletic performance.

The acute phase response presents great complexity involving local and systemic reactions. Part of these effects is the expression of the acute phase proteins (APPs) (Jain et al. 2011). The production of these proteins is triggered by inflammatory mediators, among them interleukin $1 \mathrm{~b}$, interleukin 6 and tumor necrosis factor (Leclere et al. 2015). Changes in APR can occur induced by exercise with aerobic or anaerobic pathways (Gondin et al. 2013).

Elevations of APPs concentration in serum demonstrate a peculiar acute phase reaction and indicate the clinical condition of the animal. C-reactive protein (CRP), haptoglobin (Hp) and serum amyloid A (SAA) are the most sensitive proteins in humans and animals. However, the manifestation of these proteins varies in different animal species. In horses $\mathrm{Hp}$ has medium manifestation and can be used as a marker of hemolysis during exercises (Gondin et al. 2013). The SAA is the one with the highest pronouncement in response to an acute phase reaction, followed by moderate manifestation of Hp and CRP (Cywińska et al. 2012).

SAA has low or undetectable concentration in clinically normal animals. On the other hand, it can increase from 10 to 1000 times within 24 hours after tissue damage, cell necrosis, inflammation and/or infection occur. It presents biological half-life of approximately 20 to 35 hours (Westerman et al. 2016).

Enzymes such as CK and AST are commonly used as biomarkers of muscle activity and the amount of these enzymes released from muscle depends on cell location, molecule size and injury (Fisher et al. 2014, Buzala et al. 2015, Noleto et al. 2016). It is important to use the measurement of CK and AST activity in the diagnosis of human muscle injury, equine as well as greyhound racing dogs (Lucas et al. 2015). It is also used as exercise intensity monitoring and is typical of muscle physiology (Cerqueira et al. 2018).

Considering that show jumping is a high intensity sport and of great impact, the possibility of injury is relevant. It is important to monitor the behavior of the animal's organism in situations such as that described.

The aim of this study was to verify the hypothesis that SAA, CK, AST, glucose and lactate are responsive in horses submitted to show jumping with obstacles of one meter.

\section{MATERIALS AND METHODS}

Ethics committee. The experimental design was submitted to the Ethics Committee on the Use of Animals (CEUA-UFV) and approved (CEUA-UFV 77/2015).

Animals. Ten horses, three females and seven males, Hanoverian mixed breed and Belgian saddle mixed breed, aged between seven and fifteen years old, with a mean weight of $570 \pm 95 \mathrm{~kg}$ were used. The horses were experienced and trained in the show jumping, with training routine of three times weekly and were regular participants of regional competitions (National Show Jump Concourse - CNS) of one meter high obstacles. They had similar training routine suggesting belonging to the same physical and technical level. The animals were submitted to exercise in healthy conditions, under previous physical and clinical exams, without indication of lameness or apparent sign of another disease, signaling perfect health at the moment of the competition.

Experimental design. Data were collected during a show jumping competition. The exercise consisted in making a course of approximately 350 meters, on sand floor and twelve vertical obstacles arranged along the path, with height of one meter, protocol characteristic of the sport (Fazio et al. 2014). The animals performed individual 15 minutes warm up. The horses were conducted all the time by their usual rider. After the warm-up period the heart rate monitor was installed (Polar Equine RS800CX G3 ${ }^{\circledR}$ ) and started the exercise.

Blood collection. All materials used were sterile. Blood collection was performed by venipuncture of the jugular, with previous antisepsis, using vacuum tubes containing 10\% EDTA plus sodium fluoride for glucose and lactate and plain vacuum tube without any additional to the tubes for other biochemistry parameters. The samples were centrifuged in the laboratory near the site at 3000 revolutions per minute for 10 minutes and then frozen at $-20^{\circ} \mathrm{C}$ for further analysis. The blood was collected in five moments, namely: T0 - animal in the bay, at rest immediately before being prepared for the exercise; $\mathrm{T} 1$ - immediately after the end of the journey; T2 - 30 minutes after completion; T3 - 60 minutes after the end and T4 - 24 hours after the end of the activity.

Laboratory analysis. Commercial kits were used with CK and AST being enzymatic kinetic assay; lactate by enzymatic method and glucose by the colorimetric method (Humastar 300, Human, In Vitro $\left.{ }^{\circledR}\right)$ before freezing. SAA concentrations were analyzed by enzyme-linked immunosorbent assay (Nori ${ }^{\circledR}$ Equine SAA Elisa Kit). The samples were processed in the Veterinary and Biochemistry Departments, "Universidade Federal de Viçosa", Brazil.

Statistical analysis. Results were expressed as mean \pm standard deviation. The Cochran and Bartlett test were used to verify the variance homogeneity of the data. The effect of exercise on physiological variables was evaluated by ANOVA for repeated measures. Then, the Tukey test was applied, in order to determine significant differences for each sampling time, when normality was verified. Kruskal - Wallis test was used for non-parametric analysis of variance. A $p<0.05$ value was established as significant.

\section{RESULTS}

The results of the studied variables are presented in Table 1. The animals had a mean resting heart rate of $34 \pm 3 \mathrm{bpm}$; $161 \pm 20 \mathrm{bpm}$ during activity and peak of $190 \pm 16 \mathrm{bpm}$. The activity caused alteration in the glucose, lactate and CK. The AST and acute phase protein SAA were not influenced by exercise.

\begin{tabular}{cccccc}
\multicolumn{6}{c}{$\begin{array}{c}\text { Table 1.Mean values } \pm \text { standard deviation of glucose } \\
\text { concentration (GLU), lactate (LAC), aspartate }\end{array}$} \\
aminotransferase (AST), creatine phosphokinase (CK) and \\
serum amyloid A (SAA) at different times under the influence \\
of show jumping activity \\
\multicolumn{7}{c}{ GLU } & LAC & AST & CK & SAA \\
\hline & (mg/dL) & $(\mathrm{mmol} / \mathrm{L})$ & $(\mathrm{U} / \mathrm{L})$ & $(\mathrm{U} / \mathrm{L})$ & $(\mathrm{ng} / \mathrm{mL})$ \\
\hline T0 & $97.7 \pm 13.3^{\mathrm{a}}$ & $3.8 \pm 0.8^{\mathrm{b}}$ & $206.9 \pm 39.0^{\mathrm{a}}$ & $82.8 \pm 51.2^{\mathrm{ac}}$ & $74.2 \pm 78.1^{\mathrm{a}}$ \\
$\mathrm{T} 1$ & $79.7 \pm 14.1^{\mathrm{b}}$ & $15.3 \pm 6.1^{\mathrm{a}}$ & $207.4 \pm 28.9^{\mathrm{a}}$ & $140.1 \pm 58.5^{\mathrm{b}}$ & $78.7 \pm 78.6^{\mathrm{a}}$ \\
$\mathrm{T} 2$ & $93.1 \pm 14.9^{\mathrm{ab}}$ & $6.5 \pm 3.9^{\mathrm{b}}$ & $209.2 \pm 25.7^{\mathrm{a}}$ & $135.0 \pm 85.5^{\mathrm{ab}}$ & $64.2 \pm 76.0^{\mathrm{a}}$ \\
$\mathrm{T} 3$ & $90.8 \pm 8.4^{\mathrm{ab}}$ & $5.3 \pm 2.2^{\mathrm{b}}$ & $210.4 \pm 25.4^{\mathrm{a}}$ & $121.4 \pm 54.0^{\mathrm{ab}}$ & $84.5 \pm 74.9^{\mathrm{a}}$ \\
$\mathrm{T} 4$ & $91.7 \pm 10.6^{\mathrm{ab}}$ & $5.1 \pm 1.6^{\mathrm{b}}$ & $184.9 \pm 31.1^{\mathrm{a}}$ & $74.4 \pm 43.1^{\mathrm{c}}$ & $72.6 \pm 84.6^{\mathrm{a}}$
\end{tabular}

$\mathrm{T} 0=$ Results at rest, $\mathrm{T} 1=$ immediately after exercise, $\mathrm{T} 2=30$ minutes after, $\mathrm{T} 3=60$ minutes after, $\mathrm{T} 4=24$ hours after exercise; ${ }^{\text {a,b,c }}$ different letters on the same column indicate significant difference between moments, for $\mathrm{p}<0.05$. 


\section{DISCUSSION}

This study shows that behavior of the heart rate was similar to other study with show jumping horses (Fazio et al. 2014) and represents $64.76 \%$ of the maximum, characterizing the event as of submaximal to moderate intensity (Hinchcliff et al. 2008 , Gomes 2009). The average of the speed was 282.8 meters per minute.

The exercise did not cause significant change in SAA between moments. Some horses presented values at all times very close to zero. This phenomenon has raised the standard deviation and may have contributed to the irregularity of the data. The absence of homogeneity of our studied group may be based an argument suggesting possible previous different conditions. Even the animals having similar technical level and the same training center they belong to different owners as well as their trainers. The community of competitive sport in Brazil still holds the right to keep secrets that may involve some ethical questioning. Investigation with standardbred trotters in races from 1600 to 2500 meters also did not find variation in SAA (Kristensen et al. 2014). The authors state that their results do not corroborate the hypothesis that exercise causes elevation in this acute phase protein. However, an experiment with 25 thoroughbred horses in maximum speed of 1200 and 1600 meters and found a significant difference between rest and 24 hours after the effort (Turlo et al. 2016). In our study of the 10 horses only three had high SAA in T4 and they were neither winners nor the last ones placed. The most experienced and less experienced animals showed no change. The behavior of SAA in our study can be understood by the fact that in the exercise it seems that its elevation of concentration is linked to long duration efforts (Nolen-Walston 2015).

The exercise induced a difference between $\mathrm{T} 0$ and $\mathrm{T} 1$ on glucose concentration, characterizing a depletion of glycemia but no difference between the other moments. After the exercise the values show that a similar behavior was found in a study with show jumping horses, where it is clear that the effort induced muscle glycogenolysis, which caused a migration of blood glucose into the muscle cell (Fazio et al. 2014). However, the body seeks to reestablish the glycolytic balance through high activity of sympathetic system and release of adrenaline which activate hepatic glycogenolysis (Hassan et al. 2015). Muscle glycogen recovery depends on each animal as well as individual diet and this period can take days (Marlin \& Nakervis 2004). This may be an explanation that glycemic levels, even after 24 hours, are still not the initials.

Lactate showed significant elevation only at moment T1. This hyperlactacidemia occurs parallel the glucose depletion demonstrated previously. In this case the muscle cell in intense activity and of short duration that characterizes the anaerobic effort (Roberts et al. 2014). A study with show jumping horses and intense treadmill exercise also found significant elevation in lactate levels (Fazio et al. 2014, Santos et al. 2015). Quarter horses after barrel race showed raise of $9.35 \pm 0.40 \mathrm{mmo} / \mathrm{L}$ (Souza et al. 2018). The high concentration of lactate after the activity in this study may be due to inadequate physical conditioning of the horses evaluated.

The CK of this study found similar behavior in thoroughbred horse after maximal exercise of running, significant, but with a value of much higher mean, 559.8 $203.6 \mathrm{U} / \mathrm{L}$ (Octura et al. $2014)$ in contrast to our study $(140.1 \pm 58.5 \mathrm{U} / \mathrm{L})$.This effect is expected because the rapid degradation of this compound in the CK reaction occurs because the released energy can be used to resynthesize ATP and thereby maintain the elevated intracellular ATP: ADP ratio. This activity is only possible with the elevation of the enzymatic activity of the CK (Maughan et al. 2000).This elevation of $\mathrm{CK}$ concentration after exertion due to phosphocreatine demand occurs by increasing the permeability of the muscle membrane in response to exercise also found in study with racehorses. (Hassan et al. 2015). It can be seen that the $\mathrm{CK}$ values is decaying after the peak post exertion. This phenomenon suggests that the body is reestablishing homeostasis, since energy is no longer being requested for intense work (Octura et al. 2014). Other important fact is the CK halflife is between two to six hours (Cerqueira et al.2018); this can be the reason of declining. Monitoring CK activity can be an important indicator to evaluate the impact of training on the animal, as it responds to the duration and intensity of the exercise (Buzala et al. 2015).

The behavior of AST are in agreement with other study that did not find a significant difference in thoroughbred horses after fast running with a peak of $269.25 \pm 63.87 \mathrm{U} / \mathrm{L}$ (Octura et al. 2014). They believe that the effort was not enough to induce sufficient permeability for the enzyme to manifest. Another study with show jumping horses also did not reveal significant variation of AST before and after exercise. The authors attribute the result to the good physical fitness of the animals (Santos et al. 2015). Study with quarter horses during vaquejada exercise also did not find AST alteration (Sousa et al. 2018).

\section{CONCLUSIONS}

The results refute the hypothesis that activity of show jumping with obstacles of one meter induces an acute phase reaction by raising SAA concentration as well as the biomarker of muscle activity AST. However it triggered expected metabolic change of glucose, lactate and CK.

These results do not change the position of the acute phase proteins as an important marker of inflammation. They can serve as an additional biomarker in monitoring the health of animals. It is suggested new investigation seeking answer with different height of the obstacles.

Acknowledgements.- This study was financed in part by the "Coordenação de Aperfeiçoamento de Pessoal de Nível Superior”, Brasil (CAPES) - Finance Code 001, CNPq e FAPEMIG.

Conflict of interest.- There is no conflict of interest.

\section{REFERENCES}

Buzala M., Krumrych W. \& Janick B. 2015. Usefulness of creatine kinase activity determination for assessing the effects of physical effort in horses. Pakistan Vet. J. 35(3):267-273.

Cerqueira J.A., Restan W.A.Z., Fonseca M.G., Catananti L.A., De Almeida M.L.M., Junior W.H.F., Pereira G.T., Carciofi A.C. \& De Camargo Ferraz G. 2018. Intense exercise and endurance-training program influence serum kinetics of muscle and cardiac biomarkers in dogs. Res. Vet. Sci. 121:3139. <http://dx.doi.org/10.1016/j.rvsc.2018.10.004> <PMid:30316014>

Cywińska A., Szarska E., Górecka R., Witkowski L., Hecold M., Bereznowski A., Schollenberger A. \& Winnicka A. 2012. Acute phase protein concentrations after limited distance and long distance endurance rides in horses. Res. Vet. 
Sci. 93(3):1402-1406. <http://dx.doi.org/10.1016/j.rvsc.2012.02.008> <PMid:22390917>

Fazio F., Casella S., Assenza A. \& Arfuso F. 2014. Blood biochemical changes in show jumpers during a simulated show jumping test. Veterinarski Arhiv 84:143-152.

Fédération Equestre Internationale 2013. Annual Report. Fédération Equestre Internationale, Lausanne, p.92.

Fisher A.L., Greene H.M., Talmadge R.J. \& Nout Y.S. 2014. Effect of a lactateguided conditioning program on fitness markers in the equine athlete. Annals Southern California Conference for Undergraduate Research (SCCUR), California State Polytechnic University, Pomona.

Gomes A.C. 2009. Treinamento Desportivo: estruturação e periodização. Artmed, Porto Alegre, p.89.

Gondin M.R., Foz N.S.B., Pereira M.C., Flagliari J.J., Orozco C.A.G., D’Angelis F.H.F., Queiroz-Neto A. \& Ferraz G.C. 2013. Acute phase responses of different positions of high-goal (elite) polo ponies. J. Equine Vet. Sci. 33(11):956961. <http://dx.doi.org/10.1016/j.jevs.2013.02.005>

Hassan H.Y., Aly M.A., Elseady Y.M., Nayel M.A., Elsify A.M., Salama A.A., Hassan M.S., Elbarody E.F. \& Kamar A.B. 2015. The effect of race in the clinical, hematological and biochemical biomarkers in thoroughbred horses. Alexandria J. Vet. Sci. 46(1):161-169. <http://dx.doi.org/10.5455/ ajvs.190592>

Hinchcliff K., Geor R. \& Kaneps A. 2008. Equine Exercise Physiology: the science of exercise in the athletic horse. W.B. Saunders, Philadelphia, p.211. <http://dx.doi.org/10.1016/B978-070202857-1.50003-2>.

Jain S., Gautam V. \& Naseem S. 2011. Acute-phase proteins: as diagnostic tool. J. Pharm. Bioallied Sci. 3(1):118-127.<http://dx.doi.org/10.4103/09757406.76489><PMid:21430962>

Kristensen L., Buhl R., Nostell K., Bak L., Petersen E., Lindholm M. \& Jacobsen S. 2014. Acute exercise does not induce an acute phase response (APR) in Standardbred trotters. Can. J. Vet. Res. 78(2):97-102. <PMid:24688170>

Leclere M., Lavoie-Lamourex A. \& Lavoi J.P. 2015. Acute phase protein in race horses with inflammatory airway disease. J. Vet. Intern. Med. 29(3):940945. <http://dx.doi.org/10.1111/jvim.12587> <PMid:25857218>

Lucas V., Barrera R., Duque F.J., Ruiz P. \& Zaragoza C. 2015. Effect of exercise on serum markers of muscle inflammation in Spanish greyhounds. Am. J. Vet. Res. 76(7):637-643. <http://dx.doi.org/10.2460/ajvr.76.7.637> <PMid:26111094>
Marlin D. \& Nakervis K.J. 2004. Equine Exercise Physiology. Blackwell Science, Oxford. 304p.

Maughan R.J., Gleeson M. \& Greenhaff P.L. 2000. Bioquímica do Exercício e Treinamento. Manole, São Paulo, p.47-63.

Nolen-Walston R. 2015. How to interpret serum amyloid A concentrations. AAEP Proceedings 61:130-137.

Noleto P.G., Dos Santos J.B.F., Rocha F.M., Fasano P.E., Guimarães E.C. \& Mundim A.V. 2016. Effect of a $130 \mathrm{~km}$ endurance ride on the serum biochemical profiles of Mangalarga Marchador horses. J. Equine Vet. Sci. 39:7-11 <http://dx.doi.org/10.1016/j.jevs.2015.08.010>

Octura J.E.R., Lee K.J., Woo C.H. \& Vega R.S.A. 2014. Elevation of blood creatine kinase and selected blood parameters after exercise in thoroughbred race horses. J. Res. Agricult. Anim. Sci. 2:7-13.

Roberts C., Harris P., Murray R., Cnockaert R. \& Roberts C. 2014. The relationship between blood lactate, serum muscle enzymes, jumping performance and muscle soreness in show-jumping horses. Equine Vet. J. 46(Suppl. 46):9-9. <http://dx.doi.org/10.1111/evj.12267_27>

Santos V.P.S., Gonzales F.D.G., Castro Junior F.C. \& Correio T.F.C. 2015. Hematobiochemical response to exercise with ergometric treadmil, mount training and competition in jumping horses. Arch. Vet. Sci. 20(Suppl.1):1-8.

Sousa R.A., Silva G.A., Rêgo G.M.S., Gonçalves Neto J.R., Gottardi F.P. \& Machado L.P. 2018. Effect of vaquejada exercise on the physiological and biochemical profiles of sporadic competitors and atletic horses. Acta Vet. Bras. 12(1):17-23. <http://dx.doi.org/10.21708/avb.2018.12.1.7231>

Souza L.A., Hunka M.M., Nery P.C.R., Coelho C.S., Manso H.E.C.C.C. \& Manso Filho H.C. 2018. The effect of repeated barrel racing on blood biomarkers and physiological parameters in Quarter Horses. Comp. Exerc. Physiol 14(1):47-54. <http://dx.doi.org/10.3920/CEP170019>

Turlo A., Cywinska A., Czopowicz M., Witkowski L., Jaśkiewicz A. \& Winnicka A. 2016. Racing induces changes in the blood concentration of serum amyloid A in thoroughbred racehorses. J. Equine Vet. Sci. 36:15-18. <http://dx.doi. org/10.1016/j.jevs.2015.09.008>

Westerman T.L., Foster C.M., Tornquist S.J. \& Poulsen K.P. 2016. Evaluation of serum amyloid A and Haptoglobin concentrations as prognostic indicators of horses with colic. J. Am. Vet. Med. Assoc. 248(8):935-940.<http://dx.doi. org/10.2460/javma.248.8.935><PMid:27031421> 